\title{
PERLUASAN RUANG LINGKUP BERLAKUNYA HUKUM PIDANA NASIONAL GUNA MELINDUNGI WNI DI LUAR WILAYAH NEGARA INDONESIA Oleh \\ Pantas Sianturi *
}

\begin{abstract}
ABSTRAK
Kajian ini ditujukan untuk mengetabui formulasi ruang lingkup berlakunya hukum pidana nasional pada saat ini dan pertuasannya dalam melindungi kepentingan hukum bangsa Indonesia di luar wilayah negara Indonesia. Metode pendekatan adalah yuridis normatif dengan menggunakan data sekunder yang terdiri dari bahan hukum primer, sekunder dan tersier yang diperoleh dari bahan pustaka, dengan memperhatikan prinsip pemutakhiran dan rekavensi. Spesifikasi penelitiannya bersifat deskriptif analitis, sedangkan analisis data dilakukan secara analisis yuridis historis dan yuridis komparatif. Asas nasional pasif dalam KUHP hanya melindungi kepentingan negara dari gangguan orang atau bangsa asing di luar negeri, sehingga jika terjadi suatu tindak pidana yang menimpa warga negara Indonesia, di luar negeri, maka proses hukumnya hanya diserahkan sepenuhnya terhadap hukum yang berlaku di negara tindak pidana itu dilakukan. Oleh karena itu formulasi pembaharuan kebijkan hukum pidana nasional dapat dilakukan melalui proses perbandingan dengan hukum pidana negara asing Dalam Pasal 4 RUU KUHP 2004 telah menempatkan kepentingan warga negara secara individual menjadi suatu kepentingan nasional, sehingga hukum pidana Indonesia akan dapat diterapkan terhadap orang asing yang melakukan tindak pidana terhadap warga negara Indonesia di luar negeri.
\end{abstract}

Kata Kunci : Formulasi Kebijakan, Hukum Pidana Nasional, Perlindungan Warga Negara

\section{A. LATAR BELAKANG.}

Pada dasarnya setiap negara merdeka dan berdaulat, pasti memiliki perundang-undangan tersendiri. Baik berupa hukum yang tertulis maupun tidak tertulis. Perundang- undangan itu dibutuhkan

* Pantas Sianturi, SH.MHum adalah Alumni PMIH UNDIP guna melindungi kepentingan hukum bangsa, negara dan masyarakat, dari gangguan orang-orang atau kelompok ataupun negara lain. Demikian juga dengan negara Indonesia. 
Negara Kesatuan Republik 1946 Republik Indonesia bahwa Indonesia adalah negara yang peraturan hukum pidana dinyatakan berdasar atas hukum (Rechts Staat) berlaku untuk seluruh wilayah dan bukan negara atas kekuasaan Republik Indonesia (UU No. 73 (Macht Staat). Sebab itu, maka Tahun 1958).

kedudukan hukum harus ditempatkan Karakteristik masyarakat dan di atas segala-galanya. Setiap sumber hukum yang lebih sesuai perbuatan harus sesuai dengan dengan masyarakat adalah bentuk aturan hukum tanpa kecuali. keluarga hukum (Family law) yang Ketentuan tersebut tercermin dalam bersifat pluralistik "dan monodualistik, pokok-pokok pikiran yang terkandung dalam Pembukaan Undang-Undang Dasar 1945.

Negara Indonesia memiliki berbagai jenis perundang-undangan, karena dibutuhkan berdasarkan kepentingan perkembangan masyarakat. Dinamika masyarakat selalu berkembang dalam segala sektor, maka seiring dengan itu juga harus diimbangi oleh tatanan peraturan demi tertibnya masyarakat.

Salah satu dari perundangundangan di Indonesia adalah Kitab Undang-Undang Hukum Pidana (KUHP). Perundang-undang ini mengatur masalah-masalah pidana yang lazim juga disebut di masyarakat dengan kejahatan atau kriminal.

Kitab Undang-undang Hukum Pidana tersebut asalnya dari "Wetboek van Strafrecht voor Nederlandsch Indie" merupakan warisan dari zaman Hindia-Belanda. Berlaku di Indonesia sejak tahun 1918, tepatnya tanggal 1 Januari 1918 (Stbl.1915 Nomor 732). Kemudian oleh Undang-Undang No.1 yaitu suatu nilai yang hidup dan berkembang dalam masyarakat, baik itu bersumber dari hukum adat maupun hukum agama. Paling tidak nilai-nilai hukum adat atau nilai budaya yang berkembang dimasyarakat karena sudah bersumber dan berakar di masyarakat akan lebih mudah memacu kesadaran hukum masyarakat. Apabila nilai-nilai hukum pidana bersumber dari nilai yang hidup dan berkembang dimasyarakat (living law), maka dalam hal asas legalitas pun harus diperluas. Artinya tidak lagi terpaku atas asas legalitas formal saja tapi juga dapat diterapkan asas legalitas materiil. Maksudnya dalam hal kepastian hukumpun, disamping kepastian hukum formal maka kepastian hukum material pun harus dapat diterapkan.

Sering terjadi dalam suatu perbuatan, dimana perbuatan tersebut secara formal tidak diatur dan dilarang dalam undang-undang. Tapi oleh masyarakat perbuatan itu dianggap suatu perbuatan yang layak dipidana. 
Kitab Undang-undang Hukum Pidana pada dasarnya melindungi tiga bagian besar kepentingan hukum yaitu: Kepentingan hukum negara, kepentingan hukum masyarakat dan Kepentingan hukum perorangan (individu). Ketiga kepentingan hukum dimaksud diatur secara tersebar dalam Buku II dan Buku III KUHP.

Ruang lingkup berlakunya KUHP diatur mulai dari Pasal 1 sampai dengan Pasal 9 KUHP, kalau diidentifikasi asas-asas tersebut menjadi :

1. Asas Legalitas artinya Tiada suatu perbuatan dapat dipidana kecuali atas kekuatan aturan pidana dalam perundangundangan yang telah ada, sebelum perbuatan dilakukan.

2. Jika sesudah perbuatan dilakukan ada perubahan dalam perundang-undangan, dipakai aturan yang paling ringan bagi terdakwa (Retroaktif).

3. Asas Teritorial artinya aturan pidana dalam perundangundangan Indonesia berlaku bagi setiap orang yang melakukan perbuatan pidana di dalam Indonesia.

4. Pasal 3 KUHP. Jo. UndangUnidang. No. 4. Tahun 1976 : Perluasan Asas Teritorial.

5. Azas Universal sebagaimana diatur dalam Pasal 4 ke 4 (telah diubah dengan UU No. 4 Tahun 1976).
6. Asas Nasionalitas Pasif sebagaimana diatur dalam Pasal $4 \mathrm{ke}-1, \mathrm{ke}-2$, ke-3.

7. Azas Nationalitas Aktif atau asas personalitas sebagaimana diatur dalam Pasal 5 sampai dengan Pasal 8.

Antara asas tersebut diatas dihubungkan dengan ketiga bentuk kepentingan hukum maka akan tergambar tentang luas ruang lingkup kepentingan yang dilindungi KUHP yaitu :

1. Kepentingan hukum negara seperti diatur dalam Pasal 4 ke-1, ke-2, ke-3 dan ke-4, tentang keamanan negara, ketertiban, keuangan negara, hukum Pidana Nasional dapat diberlakukan terhadap siapapun dan dimanapun. Artinya KUHP dapat menjangkau pelaku baik warga negara manapun di luar wilayah Negara Indonesia.

2. Kepentingan hukum masyarakat dan perorangan hanya dapat dilindungi berdasarkan Asas Teritorial, Asas Nasionalitas pasif dan Nasionalitas aktif. Artinya Hukum Pidana Nasional tidak dapat diberlakukan terhadap warga negara asing yang melakukan suatu tindak pidana terhadap warga negara Indonesia di luar wilayah Negara Indonesia. Asas personalitas hanya mengatur tentang KUHP dapat diberlakukan terhadap warga ne- 
gara Indonesia yang melakukan tindak pidana di luar wilayah Indonesia. Dengan kata lain bahwa KUHP mengikuti warga negara Indonesia dimanapun berada bila melakukan tindak pidana (pelaku).

Sebagaimana hakekatnya dari suatu asas hukum pada umumnya, asas-asas dari hukum pidana Indonesia itupun juga dianut sebagian besar negara-negara lain dalam hukum pidananya, dan boleh dikatakan hampir semua negaranegara di dunia menerapkan dalam hukum pidananya masing-masing. Jika benar demikian maka, sudah barang tentu dapat dikatakan asasasas tersebut merupakan asas-asas hukum pidana Internasional yang berlaku umum. Dalam pasal 38 ayat (1) statuta Mahkamah Internasional, asas-asas tersebut di atas dapat dikelompokan ke dalam salah satu sumber hukum Internasional yaitu. "The general principle of law recognized by civilized nations" atau prinsip-prinsip hukum umum yang diakui oleh bangsa-bangsa beradab. Apabila dipandang dari sudut hukum Internasional positifnya, berlakunya asas-asas hukum pidana yang secara umum sudah dipraktekkan oleh negara-negara dan diakui sebagai hukum. Kedudukanny/a dalam hukum Internasional dapat digolongkan sebagai hukum kebiasaan Internasional.

Dalam penerapanya, banyak negara-negara yang menerapkan pidana nasionalnya masing-masing dalam beberapa kasus menimbulkan perbedaan antara asas-asas tersebut. Sebagai contoh bila satu negara menerapkan Asas Teritorial terdahap suatu kasus, maka sudah barang tentu negara lain yang terlibat atas kasus tersebut akan menerapkan asas nasionalitas aktif. Demikian juga sebaliknya terhadap asas-asas yang lain.

Dalam kasus-kasus semacam ini kelihatan bahwa hukum pidana nasional dari negara-negara yang bersangkutan yang bertautan yurisdiksi satu sama lain disebut konflik atau pertautan yurisdiksi.

Konflik-konflik itu timbul antar negara, disebabkan semata-mata masing-masing negara ingin melindungi martabat Bangsa dan Negaranya masing-masing.

Pokok-pokok pikiran yang terkandung .. dalam Pembukaan Undang-Undang Dasar 1945 menjelašản bahwa. Negara melindungi segenap bangsa dan tanah tumpah darah Indonesia.

Pengertian dari pernyataan tersebut dalam pokok pokok pikiran adalah sangat luas dan dalam. Harus mampu melindungi bangsa dan negara dari gangguan siapapun, termasuk juga masalah kepentingan hukum bangsa Indonesia dimanapun 
berada, dari gangguan bangsa lain. Dalam kenyataannya Hukum Pidana Nasional (KUHP) belum mampu memberikan perlindungan bagi warga negara Indonesia secara menyeluruh.

Harus diingat bahwa sangat banyak warga negara Indonesia pada saat ini maupun waktu yang akan datang berada atau tinggal di negara asing. Mereka berada atau tinggal di luar negeri disebabkan berbagai kepentingan dan tugas. Seperti mencari pekerjaan (TKI), melanjutkan pendidikan, tugas negara, melancong atau berdarmawisata atau tugas-tugas lainnya. Harus diingat juga bahwa penyaluran tenaga kerja Indonesia (TKI) ke negara-negara asing dewasa ini sudah merupakan pemberi devisa negara yang cukup besar.

Beberapa tahun terakhir ini sering terungkap ke permukaan baik melalui pemberitaan massa media elektronik, cetak atau karena laporan langsung dari para warga negara kita itu, bahwa mereka diperlakukan secara tidak adil dan bahkan banyak yang sudah menjadi korban di negara-negara tempat mereka bekerja. Ada diantaranya menjadi korban penganiayaan pembunuhan, pemerkosaan, penipuan dan masih banyak lagi tindak pidana lainnya yang tidak terungkap.
Sudah dikemukakan secara sekilas masalah-masalah kepentingan hukum bangsa dan masyarakat Indonesia di luar wilayah negara Indonesia, maka ingin rasanya untuk meneliti lebih lanjut mengenai ruang lingkup berlakunya hukum pidana nasional.

\section{B. PERUMUSAN MASALAH}

Berdasarkan uraian dalam Latar Belakang Masalah tersebut di atas, maka permasalahan yang akan dibahas :

1.Bagaimana formulasi ruang lingkup berlakunya hukum pidana nasional pada saat ini dalam melindungi kepentingan hukum bangsa Indonesia di luar wilayah negara Indonesia.

2.Bagaimana perluasan ruang lingkup berlakunya hukum pidana nasional diformulasikan agar dapat melindungi kepentingan hukum bangsa Indonesia.

\section{KERANGKA TEOR!}

Melihat pengertian dari melindungi segenap bangsa dan tumpah darah indonesia, berarti bahwa negara harus melindungi wilayah negara Indonesia mulai dari barat sampai ke timur wilayah negara Indonesia dari gangguan siapapun dan dari negara, manapun. 
Demikian juga dengan pengertian melindungi segenap bangsa Indonesia, yang berarti bahwa setiap warga negara Indonesia baik di dalam maupun di luar wilayah Indonesia harus dilindungi dari gangguan siapapun dengan warga negara manapun.

Pembukaan UUD 1945, membuka suatu peluang untuk melakukan pembaharuan dibidang hukum, termasuk pembaharuan hukum pidana. Apabila suatu perturan perundang-undangan dirasakan sudah tidak mampu mengatur kepentingan masyarakat, maka demi perlindungan terhadap warganegara pembaharuan hukumpun harus dilakukan. Untuk mengakomodir kebutuhandan aspirasi masyarakat, maka negara Indonesia telah menentukan suatu kebijakannya. seperti Kebijakan kesejahteraan sosial (social welfare policy) dan kebijakan perlindungan social (social defence policy).

Makna dan hakekat dari pernbaharuan hukum pidana menurut Barda Nawawi Arief

1. Dilihat dari sudut pendekatan kebijakan :

a. Sebagai bagian dari kebijakan sosial, pembaharuan hukum pidana pada hakekatnya merupakan bagian dari upaya untuk mengatasi masalah-masalah sosial (termasuk masalah kemanusiaan) dalam rangka mencoba/menunjang tujuan nasional (kesejahteraan masyarakat dan sebagainya);

b. Sebagai bagian dari kebijakan kriminal, pembaharuan hukum pidana pada hakekatnya merupakan bagian dari upaya pertindungan masyarakat (khususnya upaya penanggulangan kejahatan);

c. Sebagai bagian dari kebijakan penegakan hukum, pembaharuan hukum pidana pada hakekatnya merupakan bagian dari upaya membaharui subtansi hukum (legal subtansce) dalam rangka mengefektifkan penegakan hukum.

2. Dilihat dari sudut pendekatan nilai :

Pembaharuan hukum pidana pada hakekatnya merupakan upaya melakukan peninjauan dan penilaian kembali ("reorientasi dan reevaluasi") nilai-nilai sosio politik, sosio filosofik dan sosio kultural yang melandasi dan memberi isi terhadap muatan norma dan subtantif hukumi pidana yang dicita-citakan. Bukanlah pembaharuan ("reformasi") hukum pidana apabila orientasi nilai dari hukum pidana yang dicita-citakan (misalnya KUHP Baru) sama saja dengan orientasi nilai dari hukum pidana 
lama warisan penjajahan (KUHP lama atau W.V.S). ${ }^{43}$

Kebijakan untuk memberikan perlindungan sosial diatas, salah satunya berupa memberikan perlindungan hukum bagi setiap warga negara Indonesia baik di dalam maupun di luar wilayah negara Indonesia. Termasuk juga di dalamnya upaya-upaya pencegahan dan penanggulangan tindak pidana baik yang aktual maupun yang potensial. Segala upaya untuk mencegah dan menanggulangi tindak pidana ini termasuk dalam kategori kebijakan kriminal (criminal policy).

Sebagaimana dikemukakan oleh Muladi dan Barda Nawawi Arief bahwa Politik Kriminal (Criminal policy) adalah usaha rasional untuk menanggulangi kejahatan. Semua merupakan bagian dari Politik Sosial yakni usaha dari masyarakat atau negara untuk meningkatkan kesejahteraan warganya. ${ }^{44}$

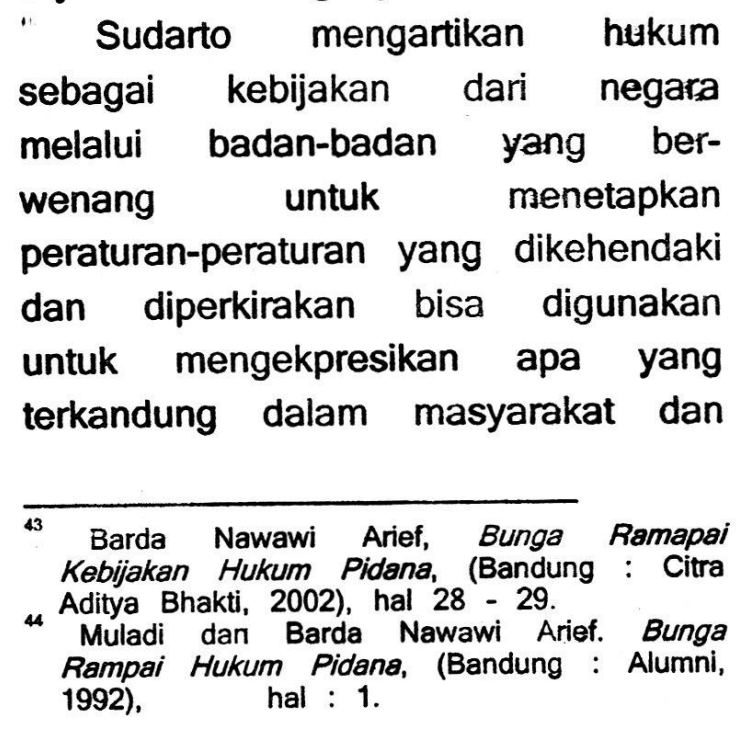

untuk mencapai apa yang dicitacitakan. $^{45}$

Djisman Samosir menyatakan, bahwa kebijakan pidana akan dilalui tiga tahap konkretisasi atau operasionalisasi atau fungsionalisasi hukum pidana yaitu :

1. Kebijakan formulatif atau legislatif, yaitu tahap perumusan atau penyusunan hukum pidana.

2. Kebijakan aplikatif atau yudikatif yaitu tahap penerapan hukum pidana.

3. Kebijakan administratif dan eksekutif, yaitu tahap pelaksanaan hukum pidana.

Berkaitan dengan uraian di atas maka pembentuk hukum dan perencana Undang-undang dalam mempersiapkan hukum pidana harus berorientasi pada kepentingan masyarakat di masa mendatang dan mengingat nilai-nilai sosial dan struktural masyarakat. ${ }^{46}$

Suatu perumusan hukum pidana yang kurang baik akan berdampak pada kedua tahap berikutnya, sehingga tahap kebijakan formulatif atau legislatif merupakan tahap yang paling penting.

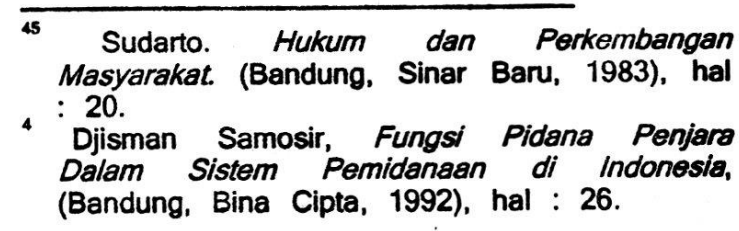

45 Sudarto. Hukum dan Perkembangan : 20 .

Dalam Sistem Pemidanaan di Indonesia, (Bandung, Bina Cipta, 1992), hal : 26. 
Sering timbul pertanyaan tentang bagaimana hukum pidana sebaiknya atau seharusnya pada masa ini dan masa yang akan datang. Pertanyaan tersebut sebenarnya sudah merupakan bidang kebijakan /politik hukum pidana (penal policy). Bagaimana sebaiknya hukum pidana itu dibuat, disusun dan digunakan untuk mengatur atau mengendalikan tingkah laku manusia dalam masyarakat. khususnya guna menanggulangi kejahatan yang dilakukan baik oleh anggota masyarakat maupun oleh penguasa. Sehingga tercermin adanya suatu gerakan untuk melindungi serta mensejahterakan masyarakat.

Dalam menyusun rumusan hukum pidana, masalah penting yang harus diperhatikan adalah subjek dan objek hukumnya, disamping kriteria perbuatan yang dilakukan (peristiwa pidana) sarta sanksi pidana suatu permasalahan hukum pidana, yang tidak dapat diabaikan adalah masalah hukum pidana yang sudah ada dan yang akan datang.

Pertanggungjawaban pidana serta sanksi pidana itu sendiri merupakan suatu masalah pokok dalam hukum pidana. Sudarto mengatakan ada beberapa hal yang dapat digunakan sebagai kriteria apakah suatu perbuatan dapat diberi suatu ancaman pidana atau tidak. Hal-hal tersebut adalah :

a. Penggunaan hukum pidana harus berusaha mewujudkan ma- syarakat adil makmur yang merata materiil dan spirituil berdasarkan Pancasila dalam wadah Negara Kesatuan Republik Indonesia. Hukum pidana bertujuan untuk menanggulangi kejahatan dan sekaligus pengugeran terhadap tindakan penanggulangan itu sendiri.

b. Perbuatan yang hendak dikehendaki yaitu yang mendatangkan kerugian baik bagi masyarakat maupun bagi diri sendiri pelakunya.

c. Usaha mencegah suatu perbuatan dengan mempergunakan sarana hukum pidana, perlu disertai dengan perhitungan biaya yang harus dikeluarkan dan hasil yang diharapkan akan dicapai (cost and benefit principle).

d. Pembuatan peraturan hukum pidana perlu memperhatikan kemampuan daya kerja dari badan-badan penegak hukum (over be lasting), yang justru mengakibatkan efek dari suatu peraturan itu menjadi berkurang. ${ }^{47}$

Romli Atmasasmita menyatakan bahwa Perserikatan Bangsa-Bangsa memberikan perhatian yang cukup besar pada bangsa-bangsa di dunia dalam upaya penanggulangan kejahatan. Masalah sistem peradilan

\footnotetext{
47 Sudarto, Hukum dan Hukum Pidana, (Bandung, Alumni, 1983), hal : 144.
} 
pidana dan penanggulangan kejahatan juga tidak luput dari perhatiannya Perserikatan BangsaBangsa yang memandang masalah sebagai bagian dari masalah yang lebih luas dan kompleks sifatnya yaitu masalah sosial, ekonomi, budaya dan politik. ${ }^{48}$.

Kejahatan merupakan prilaku menyimpang yang akan senantiasa ada dan melekat pada setiap bentuk masyarakat. Kejahatan merupakan masalah sosial yang paling tua oleh sebab itu harus ditanggulangi. Dilihat dari akibatnya kejahatan dapat mengganggu atau merusak dan merintangi tercapainya tujuan nasional dan juga mencegah penggunaan optimal- dari sumbersumber nasional.

Menurut Sudarto, bahwa penggunaan sarana penal dalam menanggulangi kejahatan tidak dapat dilepaskan keterkaitannya dengan kebijakan hukum pidana atau politik hukum pidana (criminal law policy). Sehubungan dengan hal tersebut, maka Soedarto mengemukakan bahwa melaksanakan politik hukum pidana berarti mengadakan penilaian dan pemilihan untuk mencapai hasil perundang-undangan pidana yang paling baik, dalam arti memenuhi. syarat keadilan dan daya guna. ${ }^{49}$

\footnotetext{
48 Romli Atmasasmita. Sistem. Peradilan Pidana (Criminal Justice Sistern), (Bandung, Bina Cipta 1996), hal : 89. Sudarto, op Cit hal : 161
}

A Mulder, menyatakan bahwa politik hukum pidana atau strafrechts politiek ialah garis kebijakan untuk menentukan :

1. Seberapa jauh ketentuanketentuan pidana yang berlaku perlu diubah atau diperbaharui.

2. Apa yang dapat diperbuat untuk mencegah terjadinya tindak pidana.

3. Cara bagaimana penyidikan, penuntutan, peradilan dan pelaksanaan pidana harus dilaksanakan. ${ }^{50}$

Berkaitan dengan penjelasan di atas, tentunya tidak terlepas juga mengenai pertanggungjawaban pidana serta sanksi pidana itu sendiri, di mana ketiganya merupakan masalah pokok dalam hukum pidana. Demikian juga masalah ruang lingkup berlakunya hukum pidana nasional harus terurai secara lengkap dan bagaimana pelaksanaan Undang-Undang itu sendiri, jika terjadi suatu peristiwa pidana terhadap warga negara Indonesia yang sedang berada di negara asing.

Hai tersebut diatas dapat diuraikan baik dalam formulasi hukum pidana nasional yang akan datang atau dalam perundangundangan lainnya seperti dikemukakan oleh Barda Nawawi Arief

\footnotetext{
so A. Mulder dalam Barda Nawawi Arief, Op. Cit. hal : 25 .
} 
bahwa apabila dibatasi pada hukum pidana subtantif, maka keseluruhan sistem peraturan perundangundangan (Statutory Rules) yang ada dalam KUHP (sebagai induk aturan umum) dan Undang-Undang Khusus di luar KUHP, pada hakikatnya merupakan satu kesatuan sistem pemidanaan subtantif.

Keseluruhan kesatuan perundangundangan dibidang hukum pidana substantif itu, terdiri dari "aturan umum" ("general rules") dan "aturan khusus" ("special rules"). Aturan umum terdapat di dalam KUHP (Buku 1), dan aturan khusus terdapat di dalam KUHP (Buku II dan Buku III) maupun dalam UndangUndang Khusus di luar KUHP".

\section{METODE PENELITIAN}

Penelitian ini, akan difokuskan untuk membahas substansi hukum, khususnya formulasi hukum positif (ius constitutum) dan hukum yang dicita-citakan (ius constituendum)

1. Metode Pendekatan

Masalah pokok dalam penelitian ini adalah tentang perluasan ruang lingkup berlakunya hukum pidana Nasional guna melindungi kepentingan hukum Warga Negara Indonesia (WNI) di luar wilayah Negara Indonesia. Seiring hal

\footnotetext{
Barda Nawawi Arief, Kapita Selekta Hukum Pidana, (Bandung, Penerbit, PT. Citra Aditya Bakti, 2003), hal : 136.
}

tersebut maka pendekatan yang akan digunakan adalah pendekatan yang bersifat Yuridis normatif. Menurut Ronny Hanitijo Soemitro penelitian hukum yuridis normatif merupakan penelitian kepustakaan yaitu penelitian terhadap data sekunder meliputi inventarisasi hukum positif dan penelitian untuk menemukan asäs-asas hukum serta penelitian asas-asas hukum. ${ }^{52}$

Ruang lingkup penelitian hukum normatif menurut Soerjono Soekanto meliputi :

a. Penelitian terhadap asas-asas hukum.

b. Penelitian terhadap sistimatika hukum

c. Penelitian terhadap taraf sinkronisasi hukum secara vertikal dan horizontal.

d. Perbandingan hukum dan

e. Sejarah hukum. ${ }^{53}$

Dari dua pendapat diatas mengenai penelitian hukum normatif maka penulis cenderung menggunakan pendapat Ronny Hanitijo Soemitro.

\section{Sumber Data}

Data sekunder yang digunakan dalam penelitian ini dikumpulkan dari bahan-bahan antara lain :

\footnotetext{
10Ronny Hanitijo Soemitro. Peran Metodolog dalam Pengembangan IImu Hukum. Masalah-masalah Hukum. (Majalah. FH. UNDIP No. 5. 1992. ISSN. No. 0126. 1389), hal : 35

Soerjono Soekanto dan Sri Mamudji, Penelitian Hukum Normatif. (Jakarta, PT. Raja Gratindo Persada, 1995), hal : 14.
} 
a. Bahan hukum primer, yaitu bahan-bahan hukum yang mengikat, yang terdiri dari :

1) Norma (dasar) atau kaedah dasar yaitu Pembukaan Undang-Undang Dasar 1945

2) Peraturan dasar yaitu Batang Tubuh UndangUndang Dasar 1945 dan Ketetapan MPR.

3) Peraturan

Perundangundangan Nasioanal Indonesia.

4) Peraturan

Perundangundangan diberbagai negara dengan melakukan kajian komparatif yaitu seperti; KUHP Bulgaria, KUHP China, KUHP Latvia, KUHP Perancis, KUHP Romania, KUHP Korea.

b. Bahan hukum sekunder yaitu yang memberikan suatu penjelasan mengenai bahan hukum primer, seperti rancangan Undang-Undang, hasil-hasil penelitian, hasil karya tulis kalangan hukum.

c. Bahan hukum tersier yaitu bahan-bahan yang memberikan petunjuk maupun penjelasan terhadap bahanbahan hukum primer dan sekunder antara lain :
1) Kamus
2) Ensiklopedia
3) Indeks Komulatif

4) Majalah-majalah atau jurnal hukum

3. Teknik Pengumpulan Data Sesuai dengan penggunaan data sekunder dalam penelitian ini, maka pengumpulan datapun dilakukan dengan cara mengumpulkan secara sistematis bahan-bahan kepustakaan serta. dokumen-dokumen yang berkaitan dengan data sekunder baik yang menyangkut bahan hukum primer, sekunder dan tersier yang diperoleh dari bahan pustaka, dengan memperhatikan prinsip pemutakhiran dan rekavensi. Menurut Lexi Moeloeng, data tersebut disusun secara sistematis sehingga diperoleh gambaran relatif lengkap dan klasifikasi secara kualitatif. ${ }^{54}$

Dalam penelitian ini menggunakan studi kepustakaan. Menurut Sanafiah Faisal, disebut sebagai sumber data non manusia, dilakukan untuk memperoleh data sekunder, dengan cara mempelajari peraturan perundang-undangan, literatur dokumen-dokumen resmi yang mendukung objek penelitian". ${ }^{n 5}$

Sehubungan dengan pendapat Sanafiah Faisal tersebut di atas maka dalam penelitian ini akan meniggunakan asas-asas, konsepsikonsepsi, pandangan-pandangan dok-

\footnotetext{
54 Lexi Moeloeng, Metode Penelition Kualitatif, (Bandung, Remaja Rosdakarya, 2000) hal : 2.

Sanafiah Faisal, Penelitian Kwalitatif DasarDasar dan Aplikasi, (Malang : Y.A.3, 1990) hal : 81 .
} 
trin serta kaidah hukum yang diperoleh dari referensi yang :

a. Bersifat umum yang terdiri dari teks ensiklopedia

b. Bersifat khusus yaitu berupa laporan hasil penelitian majalah ataupun jurnal hukum.

4. Analisis Data

Setiap data yang bersifat teoritis baik berbentuk asas-asas, konsepsi dan pendapat para pakar hukum termasuk kaidah atau norma hukum akan dianalisa secara yuridis kualitatif dengan menggunakan uraian secara deskriptif, yang bertitik tolak dari analisis yuridis historis dan yuridis komparatif.

Analisis yuridis digunakan untuk mengkaji secara normatif tentang formulasi ruang lingkup berlakunya hukum pidana nasional pada saat ini dan formulasi ruang berlakunya hokum pidana dimasa mendatang.

Analisis yuridis komparatif digunakan dengan cara memperbandingkan formulasi dan kebijakan legislatif negara-negara lain dalam melindungi kepentingan hukum negara dan bangsanya di wilayah negara asing.

Analisis yuridis deskriptif, dipakai untuk mengkaji kebijkan hukum pidana Nasional dimasa yang akan datang dalam melindungi kepentingan hukum bangsa dan negara di luar wilayah negara Indonesia.

\section{E. HASIL PENELITIAN DAN PEM- BAHASAN}

Berlakunya Hukum Pidana Nasional Terhadap orang Asing (WNA), dari beberapa negara, maka penulis akan mencoba untuk mengidentifikasikan dan kemudian akan menganalisis masing-masing guna mengetahui prospek kebijakan formulasi perundang-undangan di Indonesia.

1. KUHP Bulgaria (The Bulgarian Penal Code).

Dalam Art. 5 The Bulgarian Penal Code ini disyaratkan bahwa Undang-Undang Negara Bulgaria dapat diberlakukan terhadap orang asing apabila Kepentingan Republik Bulgaria atau kepentingan warga negara Bulgaria telah terpengaruh (terancam).

Dalam Art. 6 (1) The Bulgarian Penal Code disyaratkan juga bahwa Undang-undang itu dapat juga diberlakukan terhadap orang orang asing di luar negeri apa bila melakukan suatu kejahatan yang berhubungan dengan perdamaian dan kemanusiaan, dimana kepentingan negara lain atau warga negara asing terpengaruh atau terancam.

Sedangkan dalam Art. 6 (2) disyaratkan bahwa Undang-Undaning Negara Republik Bulgaria ini dapaut diberlakukan terhadap orang àsing diluar negeri apabila melakukàn 
kejahatan yang telah ditetapkan dalam kesepakatan inemasional dan Bulgaria merupakan salah satu pihak dalam kesepakatan itu.

\section{KUHP China}

Dalam Art: 8 Undang-Undang KUHP. China disebutkan bahwa Undang-Undang itu dapat diterapkan terhadap orang asing apabila melakukan kejahatan terhadap Negara RRC atau terhadap penduduk (Warga Negara) China, dengan ketentuan bahwa ancaman pidananya telah ditetapkan minimal tidak kurang dari tiga tahun penjara untuk kejahatan itu, kecuali apabila suatu kejahatan itu tidak dipidana menurut undang-undang di tempat perbuatan itu dilakukan.

Dalam Art. 9 KUHP China disebutkan bahwa Undang-Undang China dapat diterapkan apabila melakukan kejahatan-kejahatan menurut perjanjian internasional dimana Negara RRC menjadi salah satu negara yang ikut menandatangani atau sebagai anggota dan RRC melaksanakan yurisdiksi kriminal terhadap kejahatan itu sesuai dengan kewajiban dari perjanjian:

\section{KUHP Negara Korea (The} Criminal Code Of. The Republic of Korea)

Dalam Pasal 5 KUHP Korea ini disebutkan bahwa kitab UndangUndang Korea dapat diterapkan terhadap orang asing yang melakukan salah satu tindak pidana sebagai berikut di luar wilayah Republik Korea:

a) Tindak Pidana tentang Pemberontakan.

b) Tindak Pidana tentang Bendera Kebangsaan.

c) Tindak Pidana tentang Agresi dari Negeri Asing.

d) Tindak Pidana tentang mata Uang.

e) Tindak Pidana tentang suratsurat berharga, perangko dan meterai pajak.

f) Tindak Pidana Khusus tersebut Pasal 225 samapai dengan Pasal 230 tentang dokumendokumen.

g) Tindak Pidana Khusus tersebut Pasal 238 tentang segel. (setempel).

\section{Dalam Pasal 6 KUHP Korea} diatur tentang Tindak Pidana di luar negeri terhadap Negara Republik Korea dan warga negara Korea. KUHP Korea dapat di terapkan terhadap orang asing yang melakukan tindak pidana selain dari yang disebutkan terdahulu terhadap negara Korea, kecuali tindak pidana itu berdasarkan undang-undang yang berlaku ditempat dimana tindak pidana itu terjadi, tidak termasuk suatu tindak pidana atau pelaksanaan pidananya ditempat itu dihapuskan. 
5. KUHP Negara Latvia

Dalam Section 4 UndangUndang Negara Latvia disebutkan bahwa undang-undang itu berlaku bagi Warga Negara Latvia atau bukan Warga Negara Latvia, orang asing atau yang tidak mempunyai kewarganegaraan yang mempunyai izin tetap tinggal di Republik Latvia, apabila melakukan tindak pidana diwilayah teritorial negara lain maka Undang-Undang Negara Latvia dapat diterapkan.

Dalam Section 4 (2) diatur tentang anggota militer Republik Latvia yang berada di wilayah teritorial Latvia yang melakukan suatu tindak pidana, maka dapat dipertanggungjawabkan berdasarkan undang-undang Latvia, kecuali ditetapkan lain oleh perjanjian internasional yang mengikat Negara Republik Latvia.

Dalam Section 4 (3) melakukan kejahatan serius/berat di wilayah teritorial negara lain yang ditujukan kepada Republik Latvia atau kepentingan Penduduk, bagi orang asing atau yang tidak berkewarganegaraan yang tidak mempunyai izin tinggal tetap di Republik Latvia, maka undangundang ini dapat diterapkan kepadanya terlepas dari undangundang dari negara tempat kejahatan dilakukan, selama belum dipertanggungjawabkan atau dituntut menurut undang-undang dari negara tempat kejahatan. dilakukain maka undang-undang Negara

Republik Latvia dapat diterapkan.

Dalam Section 4 (4) melakukan tindak pidana di wilayah negara lain, dalam kasus-kasus yang ditetapkan dalam kesepakatan internasional yang mengikat Republik Latvia, maka bagi warga negara asing yang tidak mempunya izin tinggal di republik Latvia, terhadapnya dapat diterapkan undang-udang Republik Latvia.

\section{KUHP Perancis (French Criminal Law)}

Hukum pidana Perancis dapat diterapkan terhadap tiap kejahatan baik yang dilakuan oleh orang Perancis atau orang asing di luar wilayah Perancis, apabila korban adalah orang Perancis pada saat delik terjadi penuntutan tidak dapat dilakukan terhadap orang yang telah mendapat putusan tetap dari pengadilan asing untuk tindak pidana yang : sama, dalam hal yang bersangkutan dipidana, pidananya telah dijalani atau telah kadaluwarsa. Apabila melakukan kejahatan atau pelanggaran yang telah ditetapkan sebagai pelanggaran terhadap kepentingan fundamental dari negara dan diancam pidana menurut Bab I Buku IV, pemalsuan dan peniruan materei negara, mata uang, uang kertas atau dokumen publik yang diancam pidana menurut Pasal 442-1, 443-1, dan 444-1, dan setiap kejahatan atau pelanggaran 
terhadap diplomat Perancis atau agen-agen konsuler, atau tempattempat tinggal diplomat.

\section{Hukum Ridana Romania} (Romania Criminal Code)

Hukum pidana Romania dapat diterapkan terhadap orang asing yang tidak berkewarganegaraan dan bertempat tinggal di Romania apabila melakukan kejahatankejahatan terhadap keamanan Negara Romania atau terhadap kehidupan/nyawa Warga Negara Romania, atau yang sangat membahayakan integritas fisik atau kesehatan Warga Negara Romania.

Apabila perbuatan itu dipandang sebagai kejahatan menurut UndangUndang pidana dari negara tempat perbuatan itu dilakukan dan sipelaku berada di situ maka ketentuanketentuan diatas tidak berlaku apabila, sesuai dengan hukum yang berlaku dinegara tempat kejahatan itu dilakukan; ada alasan-alasan mencegah penuntutan pidana atau untuk - melanjutkan proses pidana atau pelaksanaan pidana; atau apabila pidana itu telah dilaksanakan atau dianggap telah dilaksanakan.

Pada prinsipnya baik hukum pidana Bulgaria, China, Korea, Latvia, Perancis maupun Romania mempunyai kesamaan dalam melindungi kepentingan hukum negara dan warga negaranya masing-masing. Negara-negara ter- sebut diatas mempunyai rumusan hukum pidana yang menempatkan kepentingan warga negaranya sebagai kepentingan nasional.

Berdasar atas penempatan kepentingan warga negara sebagai kepentingan nasional tadi, maka negara-negara tersebut dapat menerapkan hukum pidananya terhadap orang asing yang melanggar ketentuan undang-undang itu sekalipun diluar batas teritorial negaranya.

KUHP dari negara-negara diatas itu juga, sangat menghormati putusan dari pengadilan negara lain, dengan kata lain menjunjung tinggi asas "ne bis in idem" yang artinya bahwa seseorang tidak dapat dituntut keduakalinya untuk tindak pidana yang sama apa bila sudah ada putusan hakim yang telah mempunyai kekuatan hukum yang tetap.

Hal sebagaimana dimaksud di atas terdapat dalam :

- KUHP Korea: "Art. 6".

- KUHP Negara Latvia : "Section 4 (4)".

- KUHP Perancis: "Art. 113-9".

- KUHP Romania: "Art. 6".

Setelah menganalisis ruang berlakunya hukum pidana dari beberapa negara seperti yang penulis uraikan di atas, maka penulis akan mencoba membandingkannya dengan Kitab Undang-Undang Hukum Pidana 
yang berlaku sekarang ini di Indonesia.

Dalam hukum pidana yang berlaku sekarang ini di Indonesia, kalau dicermati dari keseluruhan asas-asas yang terdapat disana, mulai dari Pasal 1 sampai dengan Pasal 9 KUHP, tidak ditemukan perlindungan kepentingan hukum warga negaranya di luar negeri. Dalam arti bahwa kepentingan hukum warga negara Indonesia tidak ditempatkan sebagai kepentingan nasional yang seharusnya dilindungi.

Perlindungan kepentingan perorangan dari warga negara di luar wilayah negara Indonesia, dimana apabila warga negara Indonesia sebagai korban tindak pidana yang dilakukan oleh orang asing, tidak diatur dalam KUHP. Justru diserahkan sepenuhnya terhadap hukum yang berlaku di negara dimana tindak pidana itu terjadi, sekalipun ada kalanya negara yang bersangkutan tidak ada keseriusan untuk memproses perkara pidana dimaksudkan.

Berdasarkan bahan perbandingan hukum pidana dari beberapa negara sebagaimana telah penulis uraikan diatas, maka penulis akan mencoba mengkaji prospek kebijakan formulasi hukum pidana nasional dalam melindungi kepentingan warga negara Indonesia di luar negeri.

Sebagai suatu negara yang merdeka dan berdaulat penuh, seharusnyalah Indonesia memiliki perundang-undangan sendiri yang dapat melindungi segenap kepentingan negara dan warga negaranya dimanapun berada, sebagaimana yang tercermin dalam Pokok-Pokok Pikiran yang terkandung dalam Pembukaan Undang-Undang Dasar 1945.

Dalam konsep Rancangan Undang-Undang Kitab UndangUndang Hukum Pidana tahun 2004 diatur suatu formulasi Asas Nasinal Pasif. Sudah merupakan suatu langkah maju dalam perundangundangan Indonesia apabila konsep RUU KUHP 2004 tersebut dapat terwujud menjadi suatu UndangUndang yang resmi atau hukum positif Indonesia.

Penulis berpendapat apabila konsep tersebut terwujud menjadi suatu Undang-Undang, maka dengan sendirinya akan terjadi perluasan ruang berlakunya perundangundangan Indonesia. Dengan arti bahwa Undang-Undang Indonesia juga dapat diterapkan terhadap orang asing diluar negeri yang menggangu kepentingan negara dan warga negara.

Untuk lebih lengkap dapat dilihat dalam paragraf 2 asas nasional pasif. Dalam Pasal 4 RUU KUHP tahun 2004, Ketentuan Pidana dalam peraturan perundang-undangan indonesia belaku bagi setiap orang diluar wilayah negara Republik 
Indonesia yang melakukan tindakan pidana terhadap:

1. Warga negara Indonesia atau

2. Kepentingan negara Indonesia yang berhubungan dengan ;

a. Keamanan negara atau proses kehidupan ketatanegaraan

b. Martabat Presiden dan/ atau Wakil Presiden dan pejabat Indonesia di luar negeri;

c. Pemalsuan dan peniruan segel, cap negara, meterai, uang/mata uang, kartu kredit, perekonomian, perdagangan, dan perbankan Indonesia;

d. Keselamatan, keamanan pelayaran dan penerbangan;

e. Keselamatan dan keamanan bangunan, peralatan dan asset nasional (Negara Indonesia);

f. Keselamatan dan keamanan peralatan komunikasi elektronik;

g. Tindak pidana jabatan/ korupsi, đàn latau

h. Tindak pidana pencucian uang

Dalam Pasal 5 (Asas Universal) disebutkan bahwa ketentuan pidana dalam peraturan perundang-undangan Indonesia berlaku bagi setiap orang yang diluar wilayah negara Republik Indonesia melakukan tindak pidana menurut perjanjian atau hukum Internasional yang telah dirumuskan sebagai tindak pidana dalam peraturan perundang-undangan di Indonesia.

\section{F. KESIMPULAN}

Dari pembahasan kedua pokok permasalahan di atas, dapat ditarik suatu kesimpulan sebagai berikut :

1. Mengenai formulasi ruang lingkup berlakunya hukum pidana nasional dalam melindungi kepentingan hukum negara dan warga negara Indonesia di luar wilayah negara Indonesia :

a. Kitab Undang-Undang Hukum Pidana yang berlaku sekarang ini di Indonesia, masih KUHP peninggalan Kolonial Belanda, dalam asas nasional pasifnya hanya melindungi kepentingan negara/nasional dari gangguan orang atau bangsa asing di luar negeri.

b. Kepentingan hukum warga negara secara individual tidak ditempatkan atau tidak dianggap sebagai kepentingan nasional yang harus dilindungi dari gangguan orang asing di luar negeri.

c. Apabila terjadi suatu tindak pidana yang menimpa warga negara Indonesia, yang dilakukan oleh orang ásing di luar wilayah negara Indonesia, maka proses hukuminya hathya diserahkan sepenuhnya terhadap hukum yang berlaku di negara tindak pidana itu dilakukan. 
d. Kitab Undang-Undang Hukum Pidana tidak dapat diterapkan terhadap orang asing yang melakukan tindak pidana dimana korbannya warga negara Indonesia di luar negeri.

e. Kitab Undang-Undang Hukum Pidana Nasional belum bisa melindungi kepentingan hukum segenap bangsa Indonesia sebagaimana yang diamanatkan Pembukaan Undang-Undang Dasar 1945

2. Berkaitan dengan perluasan ruang berlakunya hukum pidana dalam prospek formulasi kebijakan hukum pidana nasional guna dapat melindungi kepentingan hukum warga negara Indonesia diluar wilayah negara Indonesia :

a. Indonesia sebagai suatu negara yang merdeka dan berdaulat penuh, harus membuat atau memformulasikan perundangundangannya yang sesuai dengan jiwa bangsa dan dapat melindungi segenap kepentingan bangsa dan warga negaranya baik di dalam maupun di luar negeri.

b. Formulasi kebijkan hukum pidana ke arah yang lebih baik dapat dilakukan melalui proses memperbandingkan hukum pidana nasional dengan hukum pidana negara asing yang kemudian dapat dilakukan proses pembaharuan hukum pidana.

c. Dalam Rancangan UndangUndang KUHP 2004 telah tercermin suatu kemajuan dibidang hukum pidana, peraturan tersebut telah menempatkan mengenai kepentingan warga negara secara individual menjadi suatu kepentingan nasional.

d. Dengan adanya Pasal 4 RUU KUHP 2004, maka dapat dikatakan suatu perubahan, karena berlakunya Hukum Pidana akan dapat diterapkan terhadap orang asing yang melakukan tindak pidana terhadap warga negara Indonesia (sebagai korban) di luar negeri.

\section{G. SARAN}

1. Sebagai suatu negara yang merdeka dan berdaulat penuh, maka Indonesia seharusnya melakukan suatu pembaharuan hukum di bidang hukum pidana, agar dapat mengakomodir semua kepentingan negara dan warga negara, baik di dalam maupun di luar wilayah negara Indonesia, agar sesuai dengan amanah dalam Pembukaan UndangUndang Dasar 1945.

2. Kepentingan hukum warga negara Indonesia sebaiknya ditempatkan sebagai kepentingan nasional, agar dapat melindungi setiap warga negara Indonesia 
yang berada di luar negeri, dari gangguan atau kejahatan orang asing.

3. Pasal 4 RUU KUHP 2004 sudah dapat mencerminkan perlindungan terhadap warga negara Indonesia di luar negeri dari kejahatan orang asing, oleh sebab itu merupakan suatu langkah maju dibidang hukum pidana apabila konsep KUHP 2004 tersebut secepatnya ditetapkan menjadi suatu Undang-Undang atau hukum positif di Indonesia. Sesuai dengan isi Pasal 4 konsep KUHP 2004 tersebut maka seharusnya ruang berlakunya KUHP dapat diperluas, sehingga Undang-Undang Indonesia dapat diterapkan terhadap orang asing yang melakukan tindak pidana yang korbannya warga negara Indonesia.

\section{DAFTAR PUSTAKA}

Atmasasmita, Romli, Sistem Peradilan Pidana (Criminal Justice System). (Bina Cipta Bàndung. 1996).

Faisal, Sanafiah, Penelitian Kwalitatif Dasar-Dasar dari Aplikasi. (Y A 3. Malang. 1990).

Hannitjo, Soemitro, Rony, Metodologi Penelitian Hukum dan Jurimetri. (Ghalia Indonesia. Jakarta, 1990).

todologi Dalam Pengembangan
IImu Hukum, Masalah-Masalah
Hukum (Majalah FH UNDIP :
No. 51992 ISSN No. 0126
1389)

Muladi \& Barda Nawawi Arif, Bunga Rampai Hukum Pidana, (Alumni, Bandung 1998).

Moleong, Lexy J., Metodologi Penelitian Kualitatif, (Remaja Rosdakarya, Bandung, 2000).

Nawawi Arief, Barda, Kapita Selekta Hukum Pidana, (Penerbit, PT. Citra Aditya Bakti Bandung, 2003).

Rampai

Kebijakan

Bunga

Pidana (Citra Aditya Bakti Bandung, 2000).

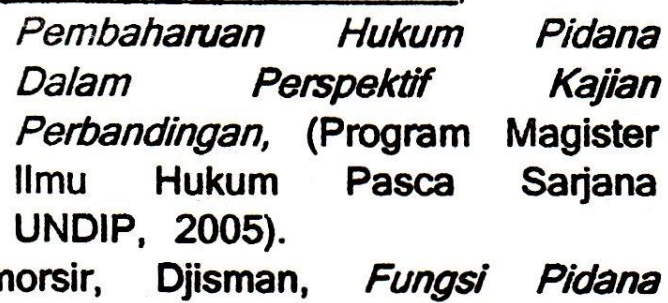
Penjara

Dalam

Sistem 
Jurnal Law Reform

Volume 1, Nomor 2, Tahun 2006
Program Studi Magister Ilmu Hukum Fakultas Hukum Universitas Diponegoro

Pemidanaan di Indonesia, (Bina Cipta Bandung. 1992).

Soekanto, Soerjono dan Sri Mamuji. Penelitian Hukum Normatif.

(Raja Grasindo Persada. Jakarta, 1995).

Sudarto, Hukum dan Perkembangan Masyarakat. (Sinar Baru, Bandung, 1983).

Pidana. (Alumni, Bandung, 1983).

Sianturi S.R., Hukum Pidana Perbandingan, (Alumni, AHM PTHM, Jakarta, 1982 - 1983). 